\title{
Kohti transkulttuurista mediaosaamista korkeakoulutuksessa
}

\author{
$\underline{y}$ \\ Kansainvälistyvässä yliopistoyhteisössä tarvitaan \\ ymmärrystä transkulttuurisista mediasuhteista. \\ Yksi tapa edistää opiskelijoiden omaa, kriittistä \\ ajattelua ja yhteisöllistä dialogia on mediaelämäkerta.
}

$\boldsymbol{y}$

KORKEAKOULUOPISKELIJAT OVAT yhä heterogeenisempi ryhmä ikäänsä, kykyihinsä, kokemukseensa ja sosiokulttuuriseen taustaansa nähden. Kun vuonna 2001 maassamme oli vajaat 7000 kansainvälistä tutkinto-opiskelijaa, niin vuonna 2013 heitä oli lähes 20 000. Lähes jokainen opiskeleva nuori käytti internetiä päivittäin jo vuonna 2015. (Tilastokeskus, 2016; ks. myös Honkimäki 2001, 101.)

Oppimisen tilat ovat laajentuneet siis korkeakouluista globaaleihin tietoverkkoihin ja yli kulttuurirajat yltäviin yhteisöihin, joissa opiskellaan yhä useammin mobiililaitteiden välityksellä (ks. Jenkins, Ito \& boyd 2016).

Opiskelijoiden kohtaamien arvojen ja informaation kulttuurinen moninaisuus törmäyttää ja avaa uusia näkemyksiä, jos sille annetaan mahdollisuus pedagogisesti rakentua osaksi luovaa ammatillista tai akateemista asiantuntijuutta. Siksi opettajien ja ohjaajien mediapedagogista osaamista ja koulutusta on hyvä tarkastella suhteessa 'transkulttuuriseen ymmärrykseen'. Käsitteellä tarkoitetaan esimerkiksi opettajan kykyä havaita ja ymmärtää opiskelijoiden yksilöllisiä elämismaailmoja erilaisista sosiaalisista ja kulttuurisista yhteyksistä käsin ja tulkita yksilön toimia kulttuurisesti moninaisissa oppimisen tiloissa (ks. Domenig 2007). On tärkeä kysyä, millaista transkulttuurista mediaosaamista tulisi opettaa korkeakouluissa, ja miten (ks. myös Kotilainen \& Pienimäki 2017).

Kulttuurinen moninaisuus merkitsee laajasti ymmärrettynä ihmisten kulttuurisia käytäntöjä yhteisöjensä jäseninä (ks. Hylland Eriksen 2014). Kulttuurin 
Keskustelu

TRANSKULTTUURISESTA

MEDIAOSAAMISESTA

ON AJANKOHTAINEN. lähtökohdista kuin natiivi suomalainen opiskelija tai opiskelija, joka on syntynyt ja elänyt Kiinan maaseudulla. Näiden kuviteltujen opiskelijoiden lähtökohdat ovat erilaiset ja eriarvoiset, kun he aloittavat esimerkiksi samassa kansainvälisessä koulutusohjelmassa.

\section{KULTTUURINEN MONINAISUUS}

HAASTAA MEDIAPEDAGOGIIKAN

käsitämme erilaisina tapoina ja käsityksinä, myös populaarin mediakulttuurin muotoina ja kommunikatiivisina käytäntöinä (esim. Fornäs 1995). Mediakulttuuria rakentuu nykyään pitkälti verkkoviestinnässä internetissä, ja yhä useammin myös käyttäjälähtöisesti erilaisina kulttuurisina ylityksinä (crossing) ja yhteen kietoutumina (converging) sekä yhteisöllisinä (multiplaying) käytänteinä ja muotoina (etm., 3; ks myös esim. Livingstone 2003).

Paneudumme kansainvälisten maisteriopiskelijoiden mediasuhteisiin, joiden voidaan olettaa rakentuvan omakohtaisina kokemuksina globaalista mediakulttuurista verkossa. Transkulttuurisuus voidaan nähdä juuri tällaisina ylirajaisina ja verkostoissa syntyneinä vuorovaikutusprosessien yhdistelminä, joissa transkulttuuriset muodot vapautuvat erottelun ongelmista (ks. Welsch 1995; Koskensalo 2009).

Lähtökohtana toimii pluralistinen epistemologia, joka ottaa huomioon erilaiset subjektiviteetit (ks. esim. Welsch, 1999). Pluralistinen nähdään kulttuurien moninaisuutena, jossa ero oman ja vieraan kulttuurin välillä vähitellen himmenee. Epistemologia perustuu kokemukseen, jossa yksilölliset havainnot ja elämänkokemus tiedon lähteinä korostuvat. Esimerkiksi korkeakoulussa opiskeleva diginatiivien sukupolvi (ks. esim. Matikainen 2016) on lähtökohdiltaan kulttuurisesti monimuotoinen, ja merkitykset, joita opiskelijat antavat verkkovälitteisille kokemuksilleen, vaihtelevat heidän erilaisista kulttuurisista lähtökohdistaan riippuen.

Opiskelija, joka on syntynyt Nigeriassa, käynyt koulunsa Intiassa brittiläisessä sisäoppilaitoksessa ja viettänyt lomansa isänsä luona New Yorkissa, merkityksellistää verkkoviestintää ja kulttuurista moninaisuutta oletettavasti laajemmin transkulttuurisista
Kulttuurisen monimuotoisuuden avaaminen ja opiskelijoiden ymmärryksen laajentuminen mediapedagogisesti on ajankohtaista yhtä lailla korkeakoulutuksessa kuin muillakin koulutusasteilla (ks. esim. Nohl 2007; Kim 2016; Kotilainen \& Pienimäki 2017). Korkeakoulutuksessa se on tärkeää erityisesti suhteessa opiskelijan omaan koulutusalaan, joka tutkimuksessamme on mediakasvatus.

Unescon kulttuurista moninaisuutta koskevassa yleismaailmallisessa julistuksessa (2001) opetussuunnitelmien ja opettajankoulutuksen uudistaminen nähdään juuri digitalisoituvien yhteiskuntien eriarvoistumisen estäjänä. Se julistaa 'digitaalilukutaidon' edistämistä sekä uuden tietoja viestintätekniikan yhä parempaa tuntemusta elinikäisen oppimisen ja osaamisen hallinnan varmistamisena. Suomessa vuonna 2016 valmistuneessa opettajien perus- ja täydennyskoulutuksen kehittämisohjelmassa kulttuurinen moninaisuus sivuutetaan maininnalla: "Opettajakoulutuksen kulttuurista moninaisuutta vahvistetaan" (OKM 2016:34, 23). Tavoite on kuitenkin sisäänkirjoitettu uusiin perusopetuksen ja lukion opetussuunnitelmiin osana monilukutaidon käsitettä, jonka katsotaan sisältävän myös median ja digitaaliset lukutaidot (ks. Perusopetuksen opetussuunnitelman perusteet 2014; Lukion opetussuunnitelman perusteet 2015).

Koulutusta ohjaavat asiakirjat ovat poliittisia linjauksia, joissa kulttuurista moninaisuutta ja digitaalisia taitoja tai mediaosaamista on ryhdytty linkittämään toisiinsa. Tämä pätee myös tutkimusteksteihin: linkitys on alkuvaiheessa. Kulttuurienvälisen dialogin tarpeesta kirjoittavat Jose Perez-Tornero ja Tapio Varis (2010) kysyvätkin (mt.,124, suom. 
kirjoittajat), ”Kuinka medialukutaito voisi edistää rauhanomaisen ja harmonisen globaalin tilan kehittymisessä”.

Kulttuurista moninaisuutta huomioivaa pedagogiikkaa kehitetään Suomessakin mediakasvatuksen hankkeilla, mutta tutkimuksessa ollaan alkuvaiheessa. Transkulttuurisesta näkökulmasta on keskusteltu niukasti, ja empiiristä tutkimusta kaivataan (esim. Vettenranta 2013; Kotilainen \& Pienimäki 2017). Suunnitelmia aikuisten mediakompetenssien edistämiseksi tai tukemiseksi on vähän, vaikka mediakasvatusta on maassamme toteutettu kymmeniä vuosia (Pääjärvi \& Palsa 2015, 200). Avaammekin keskustelun linkittämällä yhteen transkulttuurista ja mediaosaamista ja pohtimalla, miten kulttuurisen moninaisuuden huomioon ottavaa pedagogiikkaa voidaan edistää maisteriohjelmissa.

Aineistonamme on vuonna 2016 toteutettu toimintatutkimus (esim. Buckingham \& SeftonGreen 1996) mediakasvatuksen kansainvälisessä maisteriohjelmassa, jossa toimimme kurssin toteuttajina ja tutkijoina. Keräsimme transkulttuurista mediaosaamista edistävältä kurssilta oppimistehtäviä, kuten mediaelämäkertoja. Niiden avulla kuvaamme kulttuurisesti monimuotoisen opiskelijaryhmän moninaisista lähtökohdista ponnistavaa ymmärryksen avartumista, eli oppimista. Tutkimuksen analyysin viitekehyksenä on aiempi tutkimus transkulttuurisesta ja mediaosaamisesta.

Pohjaamme oppimiskäsitykseen, jonka mukaan osaamisen kehittyminen on sosiokulttuurinen tapahtuma (Vygotsky 1982). Osaaminen rakentuu sen mukaan sosiaalisten ja kulttuuristen käytänteiden vuorovaikutuksessa sekä yksilöllisen ja sosiaalisen transformaation dialogissa (esim. Hakkarainen, Paavola, Kangas \& Seitamaa-Hakkarainen 2013). Sosiokulttuurisesta näkökulmasta keskustelu transkulttuurisesta mediaosaamisesta on ajankohtainen, kun ylikulttuuriset rajat ovat yhä enemmän mediasuhteissakin artikuloinnin ja neuvottelun kohteena. Vaikka toimintatutkimuksemme sijoittuu yliopistoon, toivomme tulosten herättävän keskustelua muissakin koulutuksen diskursseissa, erityisesti koulutuspolitiikassa.
TRANSKULTTUURISTA MEDIAOSAAMISTA HAHMOTTAMASSA

Kuvaamme ylirajaisia kulttuurisuhteita, mediakulttuuri mukaan lukien (esim. Fornäs 1995), transkulttuurisina suhteina. Transkulttuurisuus voidaan nähdä erottautumisen ja yhdistymisen prosesseihin kuuluvana merkitysvälitteisenä toimintana, joka ylittää maantieteelliset ja kansalliset rajat (Martikainen, Sintonen \& Pitkänen 2006; ks. myös Frau-Meigs 2015). Transkulttuurisuudessa korostuvat jatkuva neuvottelu ja tilannesidonnaisuudet (Bradford, Allen \& Beisser 2000, 36), ja esimerkiksi jyrkkä oman ja vieraan kulttuurin välinen raja himmenee. Kulttuurien yhtäläisyydet ennemmin täydentävät toisiaan (Koskensalo 2010) ja symboleja käytetään monimerkityksellisesti (ks. Mason 2000, 12).

Erotamme transkulttuurisuuden monikulttuurisuudesta (multicultural) sekä interkulttuurisuudesta (cross-cultural, intercultural). Monikulttuurisuus muodostuu monista kulttuureista: käsite kuvaa esimerkiksi etnisten ryhmien rinnakkaista yhteiseloa usein yksittäisen maan rajojen sisällä.

Interkulttuurisuudessa vuorovaikutus tapahtuu kansallisuuksien välillä. (vrt. Berry 1976; Liebkind 2000, 14; Räsänen ym. 2002; Jokikokko \& Järvelä 2013.) Vähäiselle huomiolle jäävät tällöin yhteistyön, rajat ylittävien toimijuuksien ja eri kulttuuripiirteiden tunnustaminen ja moninaisuuden korostaminen (vrt. Salo-Lee 2005; Räsänen 2007; Jokikokko \& Järvelä 2013). Kulttuuripiirteet tulisi kuitenkin nähdä kokonaisvaltaisena elämänarvoja ja toimintaa ohjaavana filosofiana ( $\mathrm{mm}$. Talib 2005; Jokikokko 2010) sekä erilaisia elämismaailmoja (Lebenswelt) (Schütz 2003) yhdistävänä asetelmana. Tämä edellyttää syvällistä transkulttuurista ymmärrystä ja vuorovaikutusta sekä oman ja toisen erilaisuuden arvostusta. (ks. Welsch 1999; Dervin 2010.)

Dagmar Domenig (2007) lähestyy transkulttuurista kompetenssiajattelua (Transkulturelle Kompetenz) refleksiivisyyden (Selbstreflexivität) näkökulmasta. Transkulttuurinen kompetenssi pohjaa yksilön kykyyn huomata ja ymmärtää individuaalisia 


\section{MONILUKUTAITO ON}

\section{OSAAMISTA KUVAAVA \\ K ̈̈SITE JA PEDAGOGIIKKA.}

elämismaailmoja (Erfahrung) erilaisissa sosiaalisissa ja kulttuurissa konteksteissa (Hintergrundwissen) ja kykyyn yhdistää omakohtainen kokemus kohdattuihin tilanteisiin sopivaksi toimijuudeksi, narratiiviseksi empatiaksi (Narrative Empathie) (Domenig 2001b; 2001a).

Erojen sijaan etsitään elämänkokemusten yhtäläisyyksiä ja yhdistämismahdollisuuksia, jolloin transkulttuurisen osaamisen kehittyminen ohjaa yksilöä näkemään itsensä muissa (Cuccioletta 2002). Vahva itseymmärrys toimii näin voimavarana vierauden kohtaamisessa (ks. Laitinen, Nokelainen ja Pylväs 2015), ennakkoluulojen ja stereotypioinnin tunnistamisessa sekä auttaa kulttuurisen moninaisuuden aktiivista ja tasa-arvoista hahmottamista yhteiskunnan uusissa verkostoissa. (Friedenskreis Halle 2008; Koskensalo 2009).

Pohjoisamerikkalaiset tutkijat Peter Koehn ja Herbert Swick (2006) sekä Peter Koehn ja James Rosenau (2016) ovat kehittäneet transnationaalisen kompetenssin viitekehyksen (Transnational Competence Framework, TC) kulttuurisesti moninaisten kohtaamisten tueksi. Se määritellään prosessiksi, jossa objektiiviseen tahtotilaan pyritään dialogisen vuorovaikutuksen ja keskinäisen tiedonsiirron, interaktion, avulla.

Interaktion ytimessä on minietnografia (miniethnography), yksilön narratiivista muodostettu kertomus, joka toimii perustana esimerkiksi yksilön arvojen, uskomusten ja käytäntöjen kartoittamisessa. (ks. Koehn \& Swick 2006; Koehn \& Rosenau 2016.) Minietnografia asemoi jokaisen ihmisen oman elämänsä asiantuntijaksi (Sainola-Rodriques 2007).

Henkilökohtaista narratiivia laajemman käsittelyn tueksi nämä pohjoisamerikkalaiset tutkijat ovat kehittäneet transnationaalisen kompetenssin viitekehyksen. Se yhdistää analyyttisen, emotionaalisen, luovan, viestinnällisen ja toiminnallisen osaamisen, joiden ajatellaan soveltuvan yli tieteenalojen (Koehn \& Swick 2006, 549; Koehn \& Rosenau 2016). Analyyttinen osaaminen tarkoittaa esimerkiksi kykyä ymmärtää kulttuurikohtaamisissa mahdollistuvaa muutostilaa, ja emotionaalinen osaaminen on uskoa selviytyä erilaisista ylikulttuurisista kohtaamisista. Luova osaaminen merkitsee esimerkiksi viestinnällistä kykyä innovoida ja soveltaa vaihtoehtoisia näkökulmia sekä taitoa luoda osallistava ja luottamuksellinen ilmapiiri. Koehn ja Rosenau huomioivat tutkimuksessaan median yhtenä vuorovaikutuksen osallistavana ympäristönä, mutta epäilevät sen mahdollisuuksia syvemmän transkulttuurisen dialogin ja viestinnän edistäjänä (vrt. Koehn \& Rosenau 2016, 5-6).

Jotta osaaminen voi kehittyä ylikulttuurisessa kontekstissa, tarvitaan samanaikaisesti sekä subjektiivisen tilannekohtaisuuden ymmärtämistä että objektiiviseen tahtotilaan pyrkimistä. (vrt. Salo-Lee 2005; 2009; Domenig 2007). Tätä pidetään edellytyksenä myös ylikulttuurisissa oppimista tukevissa yhteisöissä. Mediasuhteet voidaan lisäksi nähdä transkulttuurisina toiminnan muotoina (esim. Kotilainen 2009). Mediakompetenssitutkimuksessa kuitenkin vasta tavoitellaan ylirajaisuutta, vaikka uusissa sosiaalisissa konteksteissa on tarvetta ymmärtää sitä nykyistä syvällisemmin. (Frau-Meigs 2015).

Ymmärryksen tarpeeseen on etsitty vastauksia esimerkiksi monilukutaidosta (New London Group 2000) ja translukutaidosta (Frau-Meigs 2013). Monilukutaidon ajatellaan toimivan sateenvarjokäsitteenä monille lukutaidoille ja pedagogiselle, myös kulttuurien moninaisuuden huomioon ottavalle pedagogiikalle (Kupiainen, Kulju \& Mäkinen 2015; Cazden ym. 1996). Se sisältyy syksyllä 2016 käyttöön otettuun perusopetuksen ja lukion uuteen opetussuunnitelmaan (Perusopetuksen opetussuunnitelman perusteet 2014; Lukion opetussuunnitelman perusteet 2015).

Ylikulttuuriseen opetukseen monilukutaito tarjoaa viitekehyksen, joka ottaa yhtäältä huomioon ylimaailmallisen yhdentyvän mediatarjonnan, niin sanotun mediakonvergenssin, ja toisaalta kasvavan kulttuurisen ja sosiaalisen moninaisuuden sekä viestinnän merkityksen erilaiset kulttuurit yhdistävissä ympäristöissä (ks. Jacobs 2012). Monilukutaitoa 
voidaan siten pitää sekä osaamista kuvaavana käsitteenä että pedagogiikkana, joka kohdistuu toimijuuteen mediakäytänteissä ja ottaa huomioon esimerkiksi opiskelijoiden subjektiivisen tiedon heidän kulttuuritaustastaan ja arjestaan (esim. Jenkins ym. 2009, 2016; Lankshear \& Knobel 2011; POPS 2014, 20-21; Kupiainen ym. 2015). Monilukutaidon tavoitteena on vahvistaa opiskelijoiden identiteettiä oppijoina moniulotteisissa ympäristöissä ja yhteisöissä (Kupiainen ym. 2015).

Monilukutaidon käsite ei ole ongelmaton. Kritiikki kohdistuu esimerkiksi siihen, että sen ajatellaan viittaavan lähinnä tekstin vastaanottoon ja lukemisen käytäntöihin (Luukka 2013) ja sisältävän monia taitoja rinnakkain eräänlaisina mosaiikkeina, kuten 'monikulttuurisuudessa', jossa monia kulttuureja katsotaan olevan rinnakkain (vrt. Kupiainen ym. 2015). Mediaosaamiseen liittyvät ilmiöt ovat siis jatkuvassa muutoksessa ja käsitteistö usein monitieteistä. Lisäksi keskustelua vaivaa painottuminen pääosin länsimaisiin lähteisiin (ks. esim. polysentrisen tutkimuksen tarpeesta Pathak-Shelat \& Kotilainen 2015). Medialukutaitojen käsitteellistämisiä, joissa on huomioitu ylikulttuurisuus ja globaalisti digitalisoituneet mediasuhteet, on suhteellisen vähän.

Divina Frau-Meigsin (2013;2015) kehittelemän 'translukutaidon' (translittératie, Transliteracy) juuret ovat ranskankielisessä ympäristössä. Termi fokusoi erityisesti digitaaliseen kulttuuria koskevaan ymmärrykseen ylikulttuurisena ilmiönä. Translukutaito ei ole pelkästään tekninen lukutaito vaan ylirajaisesti toimijuuden yhdistävä ja uudistava taito (tranformative settings), joka ohjaa esimerkiksi opiskelijoita kehittämään vallitsevia käytäntöjään ja tulkintataitojaan erilaisten mediakulttuuristen rakenteiden tunnistamisessa (Frau-Meigs 2013). Erilaisten mediakäyttäjien osaaminen, toimijuus ja resurssit yhdistyvät siis translukutaidoksi jatkuvasti muuttuvissa ja kulttuurisesti moninaisissa mediakonteksteissa.

Arnd-Michael Nohl (2007) tuo keskusteluun 'mediakäytäntöjen kulttuurin' (Medienpraxiskultur). Siinä toimijoina ovat transkulttuuriset mediakäyttäjät (transcultural users). Toimijuus muuttuvissa mediakonteksteissa nähdään oppimisena mediassa, mediasta (media-learning) sekä mediasivistyksen (media-bildung) (ks. myös Varis 1998). Mediakäytäntöjen kulttuurissa eivät siten yhdisty vain tieto ja taidot vaan myös kulttuurikontekstin arvot ja asenteet. Kompetenssin kehittyminen edellyttää tällöin transkulttuurisia mediataitoja. Niillä tarkoitetaan kykyä lukea, tulkita ja tuottaa mediaa: tekstiä, kuvaa tai ääntä tai kaikkien niitä yhdessä. Mediasivistys vastaavasti edellyttää syvällistä ymmärrystä, asenteellista muutosta, joka yhdistää laajemmin koulutuksen, sukupolvet sekä sosiaaliset että kulttuuriset aspektit (Varis 1998; Perez-Tornero \& Varis 2010).

Grace Kim (2016) määrittää mediataitoihin ja mediasivistykseen liittyvää keskustelua globaalisti transkulttuurisina digitaalisina lukutaitoina (Transcultural Digital Literacies). Määritelmä on tarkoituksellisesti monikkomuodossa. Sen tavoitteena on linkittää maantieteelliset, kulttuuriset ja sosiaaliset rajat ylittäviä tekstikäytänteitä ja kuvata kulttuurisesti moninaisia mediakäyttäjiä (ks. Kim 2016, 199-202). Määritelmä liittää siis yhtäaikaisesti usean mediakäyttäjän toimijuuden ja kulttuurisen moninaisuuden kosmopoliittisiksi käytänteiksi (cosmopolitan practice) (Hull, Stornaiuolo, Sahni 2010; ks. myös Appiah 2006).

Kosmopoliittisilla käytänteillä tarkoitetaan rajat ylittävää erilaiset kulttuurit huomioivaa asennetta (cosmopolitan mindset) (Kim 2016, 202). Esimerkiksi internetin potentiaali piilee helppoudessa tutustua mitä erilaisimpiin mediakonteksteihin ja kulttuurisesti moninaisiin näkemyksiin maailmanlaajuisesti. Kun näkemykset ja arvot kohtaavat, syntyy uutta ymmärrystä ja solidaarisuutta mutta myös konflikteja.

Laajempi ymmärrys edellyttää median käyttäjiltä asenteellista muutosta, jota voidaan tarkastella transkulttuurisen identiteettikysymyksen (self-presentation) avulla (Kim 2016). Identiteettiin kuuluvat yhtä lailla menneisyys ja tulevaisuus. Se nähdään joustavana ja uudelleen neuvoteltavana, myös ylikulttuurisuuden muotona (Hall 2005, 227). Esimerkiksi sosiaalinen media mahdollistaa yksilölle osittaisen vapautumisen omasta identiteetistä ja sosiaalisen ympäristön asettamista rajoitteista, jolloin kyky omaksua ja tulkita erilaisia identiteettejä korostuu mediaosaamisessa. Samoin korostuu kriittinen ymmärrys siitä, että ilmaisumuoto rakentuu aina sopimusten varaan ja on aina jonkun tai joidenkin 


\begin{tabular}{|c|c|c|}
\hline Kirjoittajat (Vuosi) Maa & Käsite & Määritelmä \\
\hline $\begin{array}{l}\text { Domenig, D. } \\
\text { (2001a; 2001b; 2007) } \\
\text { Sveitsi }\end{array}$ & $\begin{array}{l}\text { Transkulttuurinen kompetenssi } \\
\text { (Transkulturelle Kompetenz) }\end{array}$ & $\begin{array}{l}\text { Yksilöllinen elämismaailman huomioiminen: } \\
\text { refleksiivisyys, taustatiedot ja } \\
\text { elämänkokemus, narratiivinen empatia }\end{array}$ \\
\hline $\begin{array}{l}\text { Koehn, P. \& } \\
\text { Swick, H. (2006) } \\
\text { Koehn, P. \& } \\
\text { Rosenau, H. (2016) } \\
\text { Yhdysvallat }\end{array}$ & $\begin{array}{l}\text { Transnationaalinen kompetenssi } \\
\text { (Transnational competence, TC) }\end{array}$ & $\begin{array}{l}\text { Transnationaalisen osaamisen pedagoginen } \\
\text { viitekehys. } \\
\text { Narratiiviset tarinat eli minietnografiat } \\
\text { yhdistettynä prosessinomaiseen } \\
\text { taitojen kehittymiseen, muun muassa } \\
\text { emotionaaliseen, luovaan, viestinnälliseen } \\
\text { ja toiminnalliseen taitoon }\end{array}$ \\
\hline $\begin{array}{l}\text { New London Group (2000) } \\
\text { Australia, Yhdysvallat, } \\
\text { Englanti }\end{array}$ & $\begin{array}{l}\text { Monilukutaito (Pedagogy of } \\
\text { Multiliteracies) }\end{array}$ & $\begin{array}{l}\text { Pedagoginen viitekehys: globalisaatio, } \\
\text { kulttuurinen ja sosiaalinen erilaisuus, } \\
\text { teknologiamuutokset }\end{array}$ \\
\hline $\begin{array}{l}\text { Frau-Meigs, D. } \\
\text { (2013; 2015) } \\
\text { Ranska }\end{array}$ & Translukutaito (Translittératie) & $\begin{array}{l}\text { Transformatiivinen asetelma: } \\
\text { e-läsnäolo, kulttuurien vuorovaikutus, } \\
\text { tunne, arvot ja normit sosiaalisissa } \\
\text { konteksteissa }\end{array}$ \\
\hline $\begin{array}{l}\text { Nohl, A. M. } \\
(2007) \\
\text { Saksa }\end{array}$ & $\begin{array}{l}\text { Mediakäytäntöjen kulttuuri } \\
\text { (Medienpraxiskultur) }\end{array}$ & $\begin{array}{l}\text { Transkulttuuriset mediakäytänteet ja } \\
\text { käyttäjät } \\
\text { Oppiminen mediassa ja mediasta, media- } \\
\text { sivistys }\end{array}$ \\
\hline $\begin{array}{l}\text { Kim, G. } \\
\text { (2016) } \\
\text { Yhdysvallat }\end{array}$ & $\begin{array}{l}\text { Transkulttuuriset digitaaliset } \\
\text { lukutaidot (Transcultural Digital } \\
\text { Literacies) }\end{array}$ & $\begin{array}{l}\text { Maantieteelliset, kulttuuriset ja sosiaaliset } \\
\text { ylirajaiset tekstikäytänteet ja } \\
\text { multimodaalit oppimiskäytänteet } \\
\text { identiteetti }\end{array}$ \\
\hline
\end{tabular}

Taulukko 1. Transkulttuuristen kompetenssien ja mediaosaamisen ulottuvuuksia.

tekemä näkökulmien rajaus (vrt. Sihvonen 2009; Jenkins ym. 2009; 2016). Transkulttuuristen kompetenssien ja mediaosaamisen ulottuuvuudet -kooste (taulukko 1) kokoaa käsitteitä ulottuvuuksineen.

Vaikka lähtökohdat, kuten tieteenalat transkulttuurista ja mediakompetenssia koskeville määritelmille, eroavat toisistaan, molemmat osaamisen alueet sisältävät samankaltaisuuksia. Domenigin (2001a; 2001b) hoitotieteellisessä tutkimuksessa käyttämä 'transkulttuurinen kompetenssi' toimii elämismaailmoja yhdistävänä asetelmana, jossa hyödynnetään yksilöllinen elämänkokemus ja toimijuus.

Subjektiivinen tilannesidonnaisuus edellyttää refleksiivisyyttä, joka auttaa asennoitumaan yksilöllisiin elämismaailmoihin ja rohkaisee näkemään yhtäläisyyksiä. Monitieteellisistä tutkimuksista kehitetty transnationaalisen osaamisen viitekehys, eli transkulttuurinen kompetenssi, tarjoaa monia taitoja kohtaamisten tueksi (Koehn \& Swickin 2006, 549; Koehn \& Rosenau 2016). Osaamisen kehittyminen edellyttää objektiiviseen tahtotilaan pyrkimistä. Perustana toimivat narratiiviset minietnografit, joiden tulkinnassa hyödynnetään transnationaalisen kompetenssin viitekehystä. Se ohjaa oppijaa yhdistämään erilaisia lähtökohtia ja toimintamalleja ja sopeuttamaan saamaansa tietoa omaan toimintaansa tilanteeseen sopivalla tavalla.

Vastaavasti Nohl (2007) mediapedagogisessa tutkimuksessaan linkittää erilaiset elämismaailmat ja mediakäytäntöjen kulttuurin. Transkulttuurisia mediakäyttäjiä ja -käytänteitä yhdistää oppiminen mediassa ja mediasta. Syvemmän ymmärryksen saavuttaminen edellyytää osallistujilta mediasuhteissaan pyrkimistä objektiiviseen tahtotilaan sekä refleksiivisyyttä mediasivistyksen kaltaiseen asenteelliseen muutokseen. 


\section{OPISKELIJAT OLIVAT \\ MYÖS KANSSATUTKIJOITA.}

Frau-Meigsin (2013) mediakasvatustutkimukseen linkittyvä 'translukutaito' toimii ylirajaisessa toimijuudessa tranformatiivisena asetelmana. Se yhdistää erilaisia taitoja, käyttäjiä, toimijoita ja resursseja jatkuvasti muuttuvissa mediakonteksteissa. Mediakohtaamisten keskiöön sijoittuva e-läsnäolo (Frau-Meigs 2013; 2015) asemoi transkulttuuriset digitaaliset lukutaidot (Kim 2010) ylikansallisiksi digitaalisiksi tiloiksi, joissa linkittyvät yhtä aikaa maantieteelliset, kulttuuriset ja sosiaaliset rajat ylittävät tekstikäytänteet. Keskiössä ovat kulttuurinen moninaisuus ja toimijuus, erityisesti kulttuuri-identiteetti.

New London Groupin (2000) monialaisesti ja -tieteellisesti yhdistyvä tutkimus tarjoaa monilukutaito-käsitteellään oppimiskäytänteisiin pedagogisen viitekehyksen. Se ottaa huomioon globaalisti kasvavan kulttuurisen ja sosiaalisen erilaisuuden sekä teknologiamuutosten vaikutukset kulttuurit yhdistävissä ympäristöissä.

Käyttämämme 'transkulttuurisen mediaosaamisen’ määritelmät korostavat asenteen, osaamisen ja taitojen kehittymistä monialaisesti. Koska transkulttuurisen ja mediaosaamisen välisen yhteyden etsiminen on tutkimuksissa vasta alkutaipaleella, pohtiminen ja soveltaminen edellyttävät pedagogisesta näkökulmasta rinnalle empiiristä kehittämistä. Tutkimuksessamme tuo kehittäminen on ollut fokuksessa kurssitasolla ja maisteriohjelman opetussuunnitelmatasolla osana Erasmus+ -hanketta (eMel.org), johon osallistuimme yhtenä viidestä Euroopan yliopistosta lukuvuonna 2015-2016. Hankkeessa kehitettiin toimintatutkimuksina erilaisia mediapedagogisia verkkokursseja, jotka julkaistaan avoimessa verkkoympäristössä vuoden 2017 loppuun mennessä. Hankkeen opettajankoulutukseen suunnatuista kursseista vain esittelemämme tutkimuksen kurssi keskittyy transkulttuuriseen mediapedagogiikkaan ja osaamiseen.
Toimintatutkimuksena kehitystyö sijoittuu pragmatistiseen ja transformatiiviseen viitekehykseen (ks. esim. Mackenzie \& Knipe 2006), jotka näyttäytyvät tutkimuksessamme tavoitteena kehittää ensinnäkin sosiaalisen median ja verkon hyödyntämistä opetuksessa ja toiseksi edistää muutosta opettajankoulutuksessa transkulttuurisen mediaosaamisen ymmärryksessä. Artikkelimme tavoite on myös transformatiivinen profiloituen kriittiseen kasvatukseen mediapedagogisessa koulutuksessa (esim. Lankshear \& Knobel 2011; Kupiainen ym. 2015). Pyrkimyksenä on edistää akateemista ja koulutuspoliittista keskustelua transkulttuurisen mediakasvatuksen tarpeesta ja suunnasta.

\section{TUTKIMUKSEN TOTEUTUS}

Toimintatutkimuksen ympäristönä oli keväällä 2016 pidetty viiden opintopisteen laajuinen englanninkielinen "Transcultural perspectives in media education" -opintojakso mediakasvatuksen maisteriohjelmassa, josta voi valmistua kasvatustieteiden tai yhteiskuntatieteiden maisteriksi. Kurssin tavoitteeksi oli kirjattu "opiskelijoiden laajentunut ymmärrys yleisöjen mediankäyttöjen ylikulttuurisuudesta sekä median roolista eri kulttuureissa”. Tavoitteena oli, että opiskelijat oppivat mediapedagogisen työtavan eli mediaelämäkerran, joka mahdollisti yhteisöllisen ja dialogisen yhteistyön. Lisäksi he tuottivat audiovisuaalisen verkkouutisen. Tavoitteet kartuttivat siten yhtä aikaa opiskelijoiden omaa transkulttuurista mediaosaamista ja mediapedagogista ymmärrystä. Opiskelijat olivat aloittaneet tutkinto-ohjelman saman lukuvuoden syksynä ja perehtyneet mediakasvatuksen käsitteisiin ja tutkimusalueisiin.

Opintojaksolle osallistui 18 opiskelijaa, joista 15 oli naisia. He edustivat 14 kansallisuutta: seitsemän Euroopasta, yhdeksän Aasiasta ja kaksi Amerikan mantereelta. Pääosa oli 22-30-vuotiaita, eli nuoria aikuisia. Lisäksi mukana oli neljä yli 30-vuotiasta opiskelijaa. Sosioekonomiselta taustaltaan opiskelijat olivat vähintään keskiluokkaisia, koska opiskelu ulkomailla vaatii taloudellista resurssia, eivätkä kansainväliset opiskelijat kuulu suomalaisen opintotukijärjestelmän piiriin. 
KURSSIN PÄÄTTEEKSI

\section{OPISKELIJAT KIRJOITTIVAT \\ OPPIMISP ̈̈IVÄKIRJAN JAKSON}

AIKAISISTA MERKITYKSELLISISTÄ

OPPIMISKOKEMUKSISTAAN.

Opiskelijat rekrytoitiin tutkimukseen ensimmäisellä lähitunnilla, jolla heille esiteltiin ja jaettiin tutkimussuostumuslomake. Kaikki opiskelijat ilmoittivat halukkuutensa osallistua tutkimukseen ja allekirjoittivat suostumuksen. He olivat alusta lähtien tietoisia tutkimuksesta ja sen teemasta. Aineistojen tuottamisen näkökulmasta opiskelijat olivat myös kanssatutkijoita, sillä he toteuttivat reflektoivia tekstejä, kuten mediaelämäkerran autobiografiana (esim. Buckingham \& Sefton-Green 1996).

Koko opintojakso toteutettiin englanniksi työpajatyyppisenä työskentelynä pääasiassa pienryhmissä ja enimmäkseen verkossa. Opiskelijoiden muodostamat kolmen - neljän hengen ryhmät työskentelivät valitsemissaan verkkoympäristöissä, kuten opintojaksoa varten luodussa Moodle-ympäristössä, Google Drivessa ja suljetussa Facebook-ryhmässä.

Kurssilla oli kaksi ohjauksellista lähitapaamista, joissa opiskelijat tapasivat kasvokkain. Ensimmäinen tapaaminen oli luokassa. Opiskelijat muodostivat pienryhmät ja perehtyivät kurssin ohjelmaan, kurssin tavoitteisiin ja Moodlen artikkeliresursseihin, jotka käsittelivät käsitteitä ja uutiskriteereitä. Me ohjaajina toimineet tutkijat pidimme kaksi puolen tunnin mittaista alustusluentoa: Ensimmäinen luento käsitteli nuorten mediasuhteita kansainvälisesti vertailevien tutkimusten valossa. Toisen aiheena olivat käsitteet 'transkulttuurinen', 'monikulttuurinen' ja 'interkulttuurinen' sisältäen viestinnän. Lopuksi opiskelijoille ohjeistettiin mediaelämäkertatehtävä. Kirjoitetun, henkilökohtaisen mediaelämäkerran tuli sisältää kerrontaa lapsuudesta tähän päivään, ja sen ytimessä olivat kunkin merkityksellisimmät kokemukset suhteissa mediaan (esim. Kotilainen 2001; Eskola \& Suoranta 2001). Opiskelijoita pyydettiin kiinnittämään huomiota mediasuhteissaan transkulttuurisiin kokemuksiin, kuten vuorovaikutukseen tai yhteyksiin yli kulttuurirajojen.

Toisen kerran opiskelijat tapasivat ilman opettajia verkossa tai esimerkiksi kahvilassa. Vertaistapaamisessa käsiteltiin pienryhmittäin valmiit, luetut mediaelämäkerrat ja keskusteltiin niiden pohjalta: keskiössä olivat yhteiset ja erilaiset kokemukset. Opiskelijat työstivät yhteenvedon mediaelämäkerroista Moodleen.

Kolmannella kerralla koko kurssi tapasi luokassa verkkouutisen ohjeistusta varten. Opettaja piti $30 \mathrm{mi}-$ nuutin luennon verkkouutisista ja uutiskriteereistä. Lisäksi käsiteltiin mediaelämäkertojen yhteenvedot, joiden pohjalta opiskelijat ryhtyivät luokassa suunnittelemaan verkkouutista omissa pienryhmissään. Opettaja oli paikalla, ja häneltä saattoi kysyä apua tarvittaessa.

Neljäs kerta oli vertaistapaaminen, ja pienryhmä työsti verkkouutista uutiskriteerien pohjalta. Uutisen kohderyhmänä oli koko kurssi, eli kansainväliset vertaisopiskelijat. Matkapuhelimella videoidut uutiset tallennettiin kurssin suljettuun Facebook-ryhmään katsottavaksi ja keskusteltaviksi.

Kurssin päätteeksi kukin opiskelija kirjoitti verkko-ohjeistuksen pohjalta oppimispäiväkirjan opintojakson aikaisista merkityksellisistä oppimiskokemuksistaan. Se ohjeistettiin verkossa ja toimi oman oppimisen reflektoivana arviointina opintojaksosta. Oppimispäiväkirja palautettiin Moodleen, eikä sitä enää käsitelty yhdessä.

Toimintatutkimuksen näkökulmasta kurssi oli yhden syklin mittainen kehittävä kokeilu (ks. esim. Reason ja Bradbury 2006) kuten kyseisen Erasmus+ -hankkeen muutkin toteutukset. Se sisälsi olemassa olleen kurssin opetussuunnitelman uudistamisen ja kurssinarvioinnin Erasmus+ -hankkeen päättämin metodein. Niitä olivat opiskelijoiden alku-ja lopputestit sekä tilastolliset alku- ja loppukyselyt. Kirjalliset testit simuloivat opetustilannetta nuorisoasteella: tulos osoitti, että opiskelijoiden oma ymmärrys oli avautunut transkulttuurisista teemoista mutta pedagogisessa ymmärryksessä ei juurikaan näkynyt muutosta.

Koko hankkeen kattavassa tilastollisessa kyselyssä tämän kurssin vastaajat korostivat oppineensa eniten ryhmätehtävistä, ja toiseksi mediaelämäkerran merkityksestä. Vastausten perusteella on selvää, 
että kurssilla opittiin transkulttuurisista teemoista suhteissa mediaan ja mediasuhteisiin. (eMel 2016: Output 2). Mediaosaaminen karttui siten varsinkin yhteisen dialogin ja toiminnan kautta, henkilökohtaisen reflektion pohjalta.

Entä millaista transkulttuurista mediaosaamista kurssilla karttui? Haemme vastausta tutkimalla kurssin aikana toteutettuja kirjallisia oppimistehtäviä ja niiden analyysia, jossa olimme kumpikin mukana. Toinen meistä tutkijoista vastasi enemmän kurssin suunnittelusta, ohjauksesta ja arvioinnista toiminnan aikana, toinen taas seurasi kurssin etenemistä verkossa ja kokosi aineistot.

Tutkimuksen kirjallista kerättyä narratiivista aineistoa eli mediaelämäkertoja ja oppimispäiväkirjoja kertyi yhteensä 76 sivua, 29846 sanaa. Moni teksti sisälsi kuvia tai taulukoita, jotka tukivat kirjoitettua tekstiä, kuten taulukko merkittävimmistä mediakokemuksista. Narratiivit analysoitiin laadullisella sisällönanalyysillä, jonka tavoitteena oli selkeä ja yhtenäinen informaatio, kuitenkaan kadottamatta niitä vivahteita, joita narratiiveissa ilmiöön liittyi (vrt. Tuomi \& Sarajärvi 2006, 110). Ensin sähköisessä muodossa oleva aineisto lajiteltiin. Kokonaiskuvan hahmottamiseksi se luettiin useaan kertaan läpi ja luokiteltiin. Tämän jälkeen aineistoa teemoitettiin transkulttuurista mediaosaamista kuvaaviin laajempiin osaamisen alueisiin ja valmiuksiin (taulukko 1). Narratiiveista tarkasteltiin transkulttuuriseen mediaosaamiseen kytkeytyviä samankaltaisuuksia ja erilaisuuksia, jotka vertautuivat tutkimuskirjallisuuteen.

Kurssin toteutusta ohjasi sosiokulttuurinen näkemys oppimisesta yhteisöllisenä konstruktiona (Vygotsky 1982; Säljö 2004). Mediaelämäkerta narratiivisena elämänhistoriallisena metodina yhdisti opiskelijoiden henkilökohtaisen elämismaailman ja julkisen sosiokulttuurisen yhteiskunnallisen kerronnan ainutlaatuisina ja tilannekohtaisina tulkintoina (Kotilainen 2001; Gudmunsdottir 2007). Narratiiveissa kuvattua subjektiivista muistelutietoa jatkotyöstettiin pienryhmissä jolloin yhteisöllinen konstruktio prosessina perustui yhteiseen reflektioon ja toisilta oppimiseen (Tynjälä 1999; Engeström 2004). Yhteisen reflektion pohjalta kukin ryhmä loi videouutisen, joka julkaistiin kurssin suljetussa Facebook-ryhmässä.
Ryhmästä rakentui kurssilla siis toimija, ja yksilölliset elämismaailmat asettuivat kurssin sisäiseen julkisuuteen jaettaviksi sellaisina uutisina, joita kukin ryhmä halusi sisällöllisesti ja esittävältä muodoltaan jakaa kurssiyhteisössä. Opiskelijoiden subjektiivinen ainutkertainen tieto asetettiin siten heidän sosiokulttuurisiin yhteyksiinsä ja jaettiin koko kurssin kommentoitavaksi sekä edelleen yhteisesti rakennettaviksi uusiksi kertomuksiksi osana yhdessä elettyä elämää ja koettua todellisuutta. Siten kurssilla koettu oppiminen on osa elämää nivoutuneena elettyyn elämään. (ks. esim. McEvans 2007; Kotilainen 2001). Tutkimus ja tutkimustekstikin voidaan nähdä narratiivina, tiettyjen valintojen ja rakenteiden summana.

\section{TRANSKULTTUURISEN MEDIAOSAAMISEN KOLME ULOTTUVUUTTA}

Kirjallisten tutkimusaineistojen pohjalta opiskelijoiden transkulttuurinen oppiminen ja mediaosaaminen näyttäytyivät kolmella avainalueella, jotka nimettiin tutkimuskirjallisuuden pohjalta informatiiviseksi, kriittiseksi ja eettiseksi osaamisen alueeksi.

Informatiivisen osaamisen alue rakentui, kun tarkastelimme aineistoista toimijuutta ja transkulttuuristen mediakäyttäjien mediakäytänteitä (ks. Nohl 2007) sekä viestinnällisiä elementtejä (ks. Koehn \& Swick 2006; Koehn \& Rosenau 2010) omassa sosiokulttuurisessa kontekstissaan (New London Group 2000; Cazden ym. 1996). Aineistoissa tämä näkyi esimerkiksi konkreettisina navigointikuvauksina erilaisissa mediaympäristöissä, simuloituina kulttuurien kohtaamisina tai tiedon levittämisenä, jolloin hetkellinen osallisuus saattoi muuttua yli kulttuurirajojen luovaksi oman sisällön tuottamiseksi.

Kriittisen osaamisen alue muodostui, kun tarkastelimme aineistoja refleksiivisyyden (ks. Domenig 2001a; 2001b; 2007), e-läsnäolon (ks. Frau-Meigs 2013; 2015), sosiokulttuurisen erilaisuuden (New London Group 2000) ja analyyttisen osaamisen näkökulmasta (ks. Koehn \& Swick 2006; Koehn \& Rosenau 2010). Opiskelijoiden narratiiveissa nämä näkyivät oman elämänkokemuksen peilaamisena toisiin, ylikulttuurisen tiedon merkityksellistämisenä, mediakäytänteiden jakamisena sekä pohdintoina erilaisista vaikuttamiskeinoista. 


\section{TUtKimUS JA TUTKIMUSTEKSTI}

VOIDAAN N $\ddot{H} H \ddot{A}$

NARRATIIVINA.

Eettisen osaamisen alue niputtui yhteen, kun tarkastelimme globaalin tietoisuuden, teknologiamuutosten (ks. Domenig 2001a; 2001b; 2007; New London Group 2000) sekä mediakäytänteiden ja ylikulttuurisuuden (ks. Nohl 2007; Koehn \& Swick 2006; Koehn \& Rosenau 2010) vaikutuksia yksilöllisiin elämismaailmoihin. Erityisesti opiskelijoiden oppimispäiväkirjoissa nämä näkyivät kuvauksina omien elämismaailmojen jakamisesta ja tiedostamisesta, uuden tiedon sopimisesta, neuvottelusta ja soveltamisesta sekä osallisuuden eriarvoisuuden ymmärryksestä transkulttuurisissa mediaympäristöissä.

Seuraavassa avaamme ja kontekstualisoimme avainalueita. Aineisto-otteisiin vastaajat on merkitty sukupuolta kuvaavalla peitenimellä sekä vastaajan todellisella iällä. Englanninkieliset alkuperäisotteet ovat kirjoittajien suomentamia.

\section{Informatiivinen osaamisen alue}

\section{"Aalloilla ratsastaminen" (Hae-Won, 35)}

Aineistomme antaa viitteitä, että osallisuuden kulttuuri edisti kurssille osallistuneiden kansainvälisten maisteriopiskelijoiden informatiivisen osaamisen alueen kehittymistä. Toimijuus, verkossa navigointi, tiedon levittäminen ja luovat ja ilmaisulliset osallisuuden muodot olivat heille arkea. Osaamisaluetta tukevia kuvauksia esiintyy kaikkien opiskelijoiden mediaelämäkerroissa ja lisäksi mainintoina tärkeästä oppimiskokemuksesta oppimispäiväkirjoissa.

Opiskelijat kertoivat osallistuneensa vuosina 1999-2015 verkossa 43 erilliseen verkkopohjaiseen keskusteluryhmään, kukin ainakin yhteen. Verkkopohjaisella keskusteluryhmällä tarkoitetaan verkkoyhteisöjä, kuten Facebookia, joissa osallistujia voi esimerkiksi Suomessa voi olla kaksi miljoonaa, Kiinassa
798,2 miljoonaa ja globaalisti jopa viisi miljardia. Lisäksi opiskelijat mainitsivat käyttäneensä vuosituhannen vaihteen jälkeen internetissä 175 erillistä verkkopalvelua, joista 27 oli erilaisissa kansallisissa konteksteissa olevia sosiaalisen median sovelluksia, kuten QQ Kiinassa, Cyworld Koreassa ja VKontakte Venäjällä.

Navigoiminen ja kansallisten verkostojen saavutettavuus yhdistävät kaikkia opiskelijoita. Osallisuus ja toimijuus kansallisissa verkostoissa, esimerkiksi verkostoituminen ystävien ja tuttavien kanssa, kuvataan tarkasti. Verkottumista kuvataan helpoksi:

"Tämän lisäksi, Cyworld oli voimakkain SNS nuorten keskuudessa siihen aikaan. Se mahdollisti meille omien online mini -kotisivujen ylläpidon, joissa pystyimme kirjoittamaan päiväkirjaa, jakamaan kuvia/musiikkia, ja jättämään viestejä muiden kotisivuille. Cyworldissä oli erityinen funktio 'ratsastaa aalloilla', jonka avulla pystyin linkittymään ystävien ystäville. Digitaaliset laitteet ja alkuperäinen SNS 2000-luvun alussa sallivat minun laajentaa sosiaalista elämääni laajemmin riippumatta olinko online tai offline verkossa." (HaeWon, 35)

Opiskelijoiden narratiiviset mediasuhteet kuvataan erityisesti vapaa-ajalla voimauttavan innovatiiviseksi ja uusia toimintamalleja luovaksi yhteisölliseksi kokemukseksi. Halu vaikuttaa elämään sekä päätösten ja valintojen tekeminen yhdistää opiskelijoita yli kansallisten rajojen. Mediaosallisuus mainitaan myös haasteellisena ja epämiellyttävänä kokemuksena, josta olisi voinut välttyä esimerkiksi koulun asianmukaisella mediakasvatuksella:

"Tutustuin sosiaalisten verkostojen maailmaan itse. Se oli kova kokemus ja tein paljon virheitä, luultavasti myös liian moni muu. Uskon, että virheet, joita tein, inspiroivat minua opiskelemaan mediakasvatusta, koska tavallaan toivon, että kukaan muu ei kävisi läpi samaa, mitä minä kävin läpi. Siksi mielestäni medialukutaitoon ohjaava opetus olisi tarpeen kouluissa jo varhaisista luokista, sillä nykyään lapsilla saattaa olla oma tilinsä sosiaalisessa mediassa jo iästä seitsemän alkaen, tai jopa aikaisemmin." (Anton, 22) 
Transkulttuurisen mediaosaamisen informatiivinen alue näyttäytyy aineistossa kansainvälisten maisteriopiskelijoiden kokemuksina transkulttuurisen mediatarjonnan monipuolisesta käytöstä internetissä (Frau-Meigs 2013) ja ymmärryksenä erilaisten mediakäytänteiden kulttuurikonteksteista (Nohl, 2007).

Aineiston pohjalta pidämmekin tietoisuutta transkulttuurisesta saavutettavuudesta yhtenä merkittävimpänä transkulttuurista mediaosaamista kehittävänä tekijänä. Tutkimustuloksemme tukevat aiempaa tutkimusta siten, että osallistumista globaaleissa yhteisöissä tai transkulttuureissa verkostoissa ei juurikaan kuvata. Lisäksi koulujen rooli mainitaan transkulttuurista saavutettavuutta rajoittavana tekijänä joko puutteellisen mediakasvatuksen tai tiukkojen tietoturvasäädösten vuoksi. (vrt. boyd \& Ellison 2008.)

\section{Kriittinen osaamisen alue}

"Ensimmäinen reaktioni oli shokki" (Leyla, 22)

Transkulttuurisen mediaosaamisen kriittinen alue näyttäytyi aineistossa opiskelijoiden yhteiskunnallisena osallisuutena ja suhteellisen matalana kynnyksenä osallistua luovaan toimintaan. Tämän kaikki opiskelijat kuvasivat mediaelämäkerroissaan uteliaisuutena hankkia ja hallita sekä kyseenalaistaa ja jäsentää uutta tietoa. Oman mediasuhteen käsitteellistämistä kuvaavat aineistossa termit 'simuloida', 'analysoida' ja 'reflektoida'. Omaa mediasuhdetta kuvaillaan tällöin yleisesti harmittomana hengailuna, kuvien jakamisena ja arjen askareiden päivittämisenä lähinnä kansallisissa verkostoissa.

Lähes puolet opiskelijoista oli ennen Suomeen tuloaan asunut ulkomailla, tai heillä oli muita ylikulttuurisia kontakteja. Ylikulttuurisuus näyttäytyi aineistossamme sosiaalisen median mahdollistamina yhteyksinä kotimaahan, vuorovaikutuksena median välityksellä toiseen maahan ja yhteiskunnallisena osallistumisena, kuten hyväntekeväisyytenä, poliittisena aktiivisuutena tai vähemmistöaktivismina mediavälitteisesti. Transkulttuurisen mediaosaamisen kriittisen alueen kuvaillaan syvenevän juuri uteliaisuuden myötä "vertailemalla" samaa asiaa useasta näkökulmasta mahdollistuneissa transkulttuurisissa mediakonteksteissa. Vertailun tuloksena ylikulttuuristen yhteyksien esteet, kuten kotimaan kärjistynyt poliittinen tilanne tai internetin käyttöä rajoittava politiikka, mainitaan aineistossa. Ratkaisuksi nähdään vertaistuki, jota kuvataan transkulttuuristen yhteyksien mahdollistajana:

”Internetin rooli elämässäni on näkyvä ja avaa uusia ovia, vaikka alussa minun reaktioni olikin šokki. Ehkäpä kaikkein jännittävin ja olennaisin taito tuli opittua ystäviltäni koulussa ja yliopistossa. Koska kotimaassani on sensuuri kukaan ei oikeastaan voinut saada yhteyttä tiettyihin sivustoihin, kuten Facebookiin ja YouTubeen. Mutta mepä jaoimme jo tuolloin keskenämme kokemuksia anti-suodattimien ja VPN:n käytöstä.” (Leyla, 22)

Narratiiveissa yksilölliset mediaelämäkerrat strukturoivat opiskelijoiden transkulttuurisia mediakokemuksia. Ne myös mahdollistavat yksilöllisen itsereflektoinnin ja yhteisöllisen kokemusten jakamisen. Mediaelämäkertakoosteiden ryhmässä jäsentäminen taas näyttäytyy aineistossa dialogisuutena sekä itsetuntemuksena ylikulttuurisen median käyttäjänä että transkulttuurisen merkityksen avaajana. Näkökulmat ylikulttuurisista samankaltaisuuksista, eroista ja yhdistämismahdollisuuksista avasivat tutkimukseen osallistuneiden mukaan omaan elämismaailmaan liittyviä kulttuurisia kerroksia, jotka ilman ryhmätehtävässä tehtyä yhteistyötä jäisivät näkymättömiksi:

"Ennen Suomeen tuloani en ollut tiennyt, että elämääni sensuroitaisiin tai en olisi ollut vapaa." (Li, 22)

Kriittisen osaamisen alue rakentuu sosiaalisesta, poliittisesta ja taloudellisesta näkökulmasta paikallisiin ja globaaleihin mediakonteksteihin. Aineistomme pohjalta transkulttuurinen käsitteellistäminen on merkittävimpiä tekijöitä transkulttuurisen mediaosaamisen kehittymisessä.

Pienryhmässä jaettujen kokemusten mainitaan syventäneen transkulttuurista ymmärrystä, mikä ohjasi opiskelijoita kriittiseen, käsitteellistävään 
JAETUT KOKEMUKSET

SYVENSIVÄT

TRANSKULTTUURISTA

YMMÄRRYST $\ddot{A}$.
"Olen antanut Facebookille hauskan nimen, joka on 'loputon säiliö kaikenlaisista tunteista'. Tämä johtuu siitä, että löydän Facebookista tuhansia päivityksiä, joissa käsitellään ihmisten henkilökohtaisia tunteita: onnellisuutta, hermostuneisuutta, vihaa, surua, kateutta, masennusta ja niin paljon enemmän. On toki luonnollista ilmaista tunteitaan, sillä jokainenhan meistä haluaa tulla huomatuksi." (Mei Mei, 26) dialogiin. Itsetuntemus median käyttäjänä ja ymmärrys toisen asemasta syveni juuri näiden kohtaamisten myötä: tämä mainitaan erityisesti useissa oppimispäiväkirjoissa. Aineiston pohjalta transkulttuurisen mediaosaamisen kriittisen alueen voidaan katsoa edistävän ymmärrystä moninaisten mediakulttuuristen rakenteiden tunnistamisesta, mediaympäristöistä, todellisuuksista ja digitaalisista lukutaidoista (New London Group 2000; Frau-Meigs 2013; Kim 2016), niiden vaikutuksesta yksilön elämään sekä edesauttavan faktan ja fiktion erottamisessa. (kts. Koehn \& Swick 2006; Nohl 2007; Koehn \& Rosenau 2016;). (ks. myös taulukko 1.)

\section{Eettinen osaamisen alue}

"Loputon säiliö kaikenlaisia tunteita" (Mei Mei, 26)

Opiskelijoiden elämismaailmat ovat yllättävän jaettuja ja läpinäkyviä. Jaetuista kokemuksista merkittävimmät liittyvät osallisuuteen. Sitä edesauttavina tai rajoittavina tekijöinä mainittiin sosiaaliset, taloudelliset tai poliittiset tekijät. Erot eivät näyttäydy pelkästään maanosien vaan myös maiden välillä, tulivatpa opiskelijat sitten Euroopasta, Aasiasta tai Amerikasta. Keskiössä ovat kulttuurien moninaisuus, dialogi ja vastuu omasta toiminnasta. Narratiiveissa tiedon soveltaminen, esiintyminen ja neuvottelu näkyvät yli kulttuurirajojen mahdollisuutena tai sen puutteena tulla huomioiduksi, omien näkökulmien jakamisena ja yhteisen ymmärryksen luomisena. Seuraava esimerkki käsittelee osallisuutta ja siihen liittyen mahdollisuutta ilmaista tunteita ja tehdä valintoja:
Kaikki opiskelijat mainitsivat jaetut mediaelämäkerrat tärkeinä oppimiskokemuksina. Kunkin opiskelijan elämismaailma koostui uniikeista kokemuksista suhteessa mediaan, ja opiskelijat kuulivat transkulttuurisen näkökulman autenttisilta mediankäyttäjiltä. Tämä oppimiskokemus avasi opiskelijoille dialogin mahdollisuuden. He korostivat juuri yhteistyön merkitystä syvemmän ymmärryksen syntymiselle.

Mediaelämäkerrat tekivät näkyväksi sen, että mediassa esiintyvien eri näkökulmien hahmottaminen ja ymmärtäminen koetaan liian usein itsestään selväksi, ja asioita, kuten sananvapautta, yleistetään. Ylikulttuurisuuden syvällinen ymmärtäminen edellyttäkin, että samankaltaisuuksia ja eroja tehdään näkyväksi, jolloin mediaelämäkerrat avaavat mahdollisuuden tunteiden pohdinnalle myös tarinallisuuden avulla. Erilaiset identiteettitarinat toimivat siten siltana eettiseen osaamisen alueeseen vaikkapa roolien kautta, mikä on tärkeää empatian ja tunteiden syvällisemmän ymmärryksen synnyssä.

"Mielestäni sillä ei ole merkitystä, mikä tekee kulttuureista erilaisia. On lukuisia tekijöitä, jotka muovaavat kulttuureita, kuten historialliset, taloudelliset, etniset tai jopa poliittiset tekijät. Vaikka sanomme, että olemme juuri nyt tässä globaalisti teknologian välityksellä verkottuneessa yhteiskunnassa, yllättävää tai ei, meillä ei vieläkään ole samanlaista mediaelämää. Oma kulttuurimme tuo meille myös ainutlaatuisen mediaelämän, joka on täysin erilainen ihmisillä, jotka ovat muista kulttuureista. Siksi meillä kaikilla on hyvin erilaisia mediaelämäkertoja. - Jokainen pieni mahdollisuuskin voi olla mahdollisuus luoda siltoja kulttuurien välille, jolloin oppiminen voidaan suorittaa yksinkertaisella ja tarkoituksenmukaisella tavalla." (Yun, 22) 
Aineiston pohjalta eettinen osaamisen alue edistää tietoisuutta omasta transkulttuurisesta vastuusta transkulttuurisissa mediaympäristöissä. Tärkeänä oppimiskokemuksena mainittiin yhdessä jaettu tieto yksilöllisissä elämismaailmoissa ilmenevästä eriarvoisuudesta, median vaikutuksista omiin tunteisiin, käsityksiin ja erilaisiin rooleihin. Jaetun tiedon mainittiin kasvattavan transkulttuurista ymmärrystä. Tutkimuksemme antaa viitteitä, että opiskelijoiden jakamat kokemukset auttoivat rakentamaan uudelleen omaa narratiivia suhteessa toisiin, ja edistivät siten transkulttuurisen identiteetin rakentumista.

Eettinen osaamisen alue liittää aiemman tutkimuksen pohjalta aineiston ja tutkimuskirjallisuuden osallisuuden kuiluun, tiedon läpinäkyvyyteen ja eettisiin haasteisiin (New London Group 2000; Jenkins ym. 2009, 2016). Ymmärrys yksilöllisistä elämismaailmoista, (Domenig, 2007), dialogin ja omien tunteiden ilmaisun merkityksestä (Koehn \& Swick 2006; Nohl 2007) sekä tietoisuus muuttuvista mediaympäristöistä ja niiden vaikutuksesta yksilöön (Frau-Meigs 2013) korostuvat. (ks. myös taulukko 1). Eettinen osaamisen alue yhdistyy käytänteiksi, joissa kansalaisuuden merkitys kapenee ja globaali maailmankansalaisuus laajenee (Kim 2016). Dialogin merkitys korostuu rakennettaessa maailmankuvat ylittävää eettistä ulottuvuutta (Appiah 2006). (ks. myös taulukko 1.)

\section{PÄÄTELMÄT}

Tutkimuksemme avaa keskustelua transkulttuurisesta näkökulmasta suhteessa mediaosaamiseen, media- ja informaatiolukutaitoihin sekä mediakasvatukseen. Sen pohjalta voi hahmottaa transkulttuurisessa mediaosaamisessa informatiivisen, kriittisen ja eettisen alueen. Laadullisen toimintatutkimuksemme aineiston pohjalta ei voi määritellä yksittäisiä taitoja vaan laajemmin oppimiseen ja opetukseen liittyviä osaamisen avainalueita ja teemoja.

Informatiivinen osaamisen alue esiintyy opiskelijoiden narratiiveissa median transkulttuurisena saavutettavuutena ja sen myötä osallisuutena tai osallisuuden puutteena. Tulokset tukevat aiempaa tutkimusta kahdesta näkökulmasta: Ensinnäkin aineistossa navigoimista yli kulttuurirajojen hyödynnetään erilaisina mediailmaisun muotoina. Toiseksi transkulttuurisen mediaosallisuuden eriarvoisuus on nähtävissä opiskelijoiden välillä yli kansallisten rajojen (Jenkins \& ym. 2009, 2016; Kim 2016). Mediaosallistuminen näkyy lähinnä sosiokulttuurisena digitaalisena eriytymisenä eikä niinkään kolonialistiseen ajatteluun pohjautuvina pääsyn (access) digikuiluina (Peter \& Valkenburg 2006).

Transkulttuurisen mediaosaamisen kriittinen osaamisen alue näyttäytyy aineistossa itsensä peilaamisena eli refleksiivisyytenä, joka avaa mahdollisuuden ylikulttuuriseen kyseenalaistamiseen, stereotypioiden purkamiseen ja erilaisten arvomaailmojen pohjalta transkulttuuriseen käsitteellistämiseen (esim. Cazden ym. 1996; Kim 2016). Eettinen osaamisen alue rakentuu tietoisuutena eettisesti kestävästä ja vastuullisesta toiminnasta transkulttuurisessa mediassa (New London Group 2000; Cazden ym. 1996). Eettisestä näkökulmasta tärkeiksi nousevat aineistossa esimerkiksi erilaiset kosmopoliittiset käytänteet (cosmopolitan practice) (Hull, Stornaiuolo, Sahni 2010; ks. myös Appiah 2006). Niillä tarkoitetaan rajat ylittävää, erilaiset kulttuurit huomioivaa asennetta (cosmopolitan mindset) (Kim 2016, 202), jossa lähtökohtana on transkulttuurinen kansalaistoiminta yli rajojen, myös verkossa.

Transkulttuurisen mediaosaamisen tiedostamiselle ja edistämiselle on tarvetta kaikilla kouluasteilla, vapaassa sivistystyössä ja mediassa, jotta saadaan otetta esimerkiksi etnisiä vähemmistöjä ja pakolaisia koskevaan vihapuheeseen ja disinformaatioon verkossa (ks. Kotilainen \& Pienimäki 2017). Transkulttuurinen mediaosaaminen ei siten kapeudu yksin kansainväliseen maisterikoulutukseen, tutkimuksemme kontekstiin.

Miten transkulttuurisia mediakompetensseja tulisi edistää? Tulostemme pohjalta ymmärrystä transkulttuurisista mediasuhteista voidaan rakentaa pedagogisilla ratkaisuilla, jotka edistävät opiskelijoiden omaa, kriittistä ajattelua ja yhteisöllistä dialogia. Tutkimuksessamme yksilölliset mediaelämäkerrat ja niiden jakaminen opiskelijalähtöisesti 
opintoryhmän verkkoympäristössä mahdollistivat samanaikaisesti henkilökohtaisen ja yhteisöllisen kokemuksen. Tässä pääosin kansainvälisten maisteriopiskelijoiden narratiivisia aineistoja hyödyntävässä toimintatutkimuksessa tulokset ovat yksilöllisiä, kun jokaisen opiskelijan elämismaailma koostui uniikeista kokemuksista suhteessa mediaan, mutta ne muodostuivat yhteisöllisiksi, kun opiskelijat kuulivat transkulttuurisen näkökulman jaettuina opiskelijatovereiltaan, autenttisilta toisilta mediankäyttäjiltä. Lisäksi tämä subjektiivinen yhteisöllisesti jaettu tieto asetettiin sosiokulttuurisiin yhteyksiin maisteriopinnoissa, kun se jaettiin koko kurssille kommentoitavaksi, samalla edelleen rakennettaviksi uusiksi kertomuksiksi osana elettyä elämää ja koettua todellisuutta (esim. Kotilainen 2001).

Yleispäteviä toimintamalleja ei välttämättä edes ole mahdollista löytää (Jokikokko \& Järvelä 2013), mutta esittämäämme pedagogista tapaa voi aina soveltaa erilaisissa pedagogisissa konteksteissa. Käsitteellisesti tutkimusta transkulttuurisesta mediaosaamisesta olisi hyvä jatkaa tilastollisella otteella, tutkimuksemme aineistoa laajemmalla aineistolla ja monimetodisesti.

Monilukutaitoja ja mediaosaamista koskeva käsitteistö on monitieteinen, ja ilmiöt jatkuvassa muutoksessa. Samoin kulttuurien moninaisuutta ja transkulttuurisuutta koskeva osaaminen on jatkuvassa muutoksessa (esim. Laitinen, Nokelainen \& Pylväs 2015, 76). Tarvitsemme yhtä aikaa erilaisia tutkimuksia suhteessa transkulttuuriseen mediaosaamisen ja sitä tukevaan pedagogiikkaan.

Tutkimuksemme osoittaa tulkinnallisen rajallisuutensa mutta toimii kontekstikritiikkinä pedagogiseen tutkimukseen, joka jättää huomiotta oppijoiden mediakulttuurit (Buckingham \& SeftonGreen 1996). Tarvitaan edelleen käytäntölähtöistä uudistavaa tutkimusta, joka edistää tapoja kehittää pedagogiikassa oppijalähtöisyyttä, tutkimusperustaisuutta ja yhteisöllisyyttä varsinkin kulttuurisessa sensitiivisyydessä.

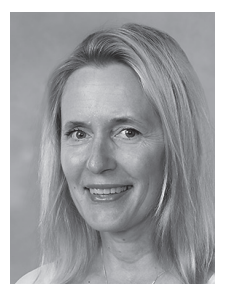

MINNA KOPONEN

KM, tohtorikoulutettava

Kasvatustieteiden tiedekunta

Tampereen yliopisto

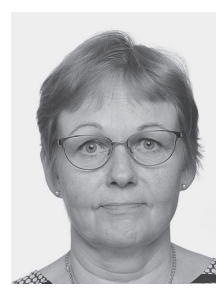

SIRKKU KOTILAINEN

FT, professori

Viestintätieteiden tiedekunta

cOMS

Tampereen yliopisto

\section{LÄHTEET}

Appiah, K. A. (2006). Cosmopolitanism: Ethics in a world of strangers. New York: W.W. Norton.

Bradford, L., Allen, M., \& Beisser, K. L. (2000). Metaanalysis of intercultural communication competence research. World Communication, 29(1), 28-51.

Berry, J.W. (1976). Human Ecology and Cognitive Style: Comparative Studies in Cultural and Psychological Adaptation. New York: Sage Publications.

Buckingham, D. \& Sefton-Green, J. (1996). Cultural studies meet Action Research in the Media Classroom. Educational Action Research, 4(2), 223-244.
Cazden, C., Cope, B., Fairclough, N., Gee, J., et al. (1996). A Pedagogy of Multiliteracies: Designing Social Futures. Harvard Educational Review, 66(1), 60-92. http://vassarliteracy.pbworks.com/f/ Pedagogy+of+Multiliteracies_New+London+Group. pdf. (20.3.2017)

Cuccioletta, D. (2001-2002). Multiculturalism or Transculturalism: Towards a Cosmopolitan Citizenship. London Journal of Canadian Studies, Vol 17. Plattsburgh State University of New York, Interdisciplinary Research Group on the Americas. http://www.canadian-studies.net/lccs/LJCS/Nol_17/ Cuccioletta.pdf. (20.9.2015) 
Dervin, F. (2010). Assessing intercultural competence in Language Learning and Teaching: a critical review of current efforts. Teoksessa Dervin, F. \& SuomelaSalmi, E. (toim.) New Approaches to Assessment in Higher Education. Bern: Peter Lang, 157-173.

Domenig, D. (2001a). Einführung in die transkulturelle Pflege. Teoksessa Domenig, D. (toim.). Professionelle transkulturelle Pflege. Handbuch für Lehre und Praxis in Pflege und Geburtshilfe. Bern: Verlag Hans Huber, 139-158.

Domenig, D. (2001b). Migration, Drogen, transkulturelle kompetenz. Bern: Verlag Hans Huber, 200.

Domenig, D. (2007). Das Konzept der transkulturellen Kompetenz. Teoksessa D. Domenig (toim.) Transkulturelle Kompetenz. Lehrbuch für Pflege-, Gesundheits- und Sozialberufe. Bern: Huber \& Lang-Hogrefe AG, 165-189.

eMel. (2016). Output 2 - Competencies Evaluation. Transcultural Perspectives in Media Education. Ei julkinen asiakirja.

Engeström, Y. (2004). Ekspansiivinen oppiminen ja yhteiskehittely työssä. Tampere: Vastapaino.

Eskola J. \& Suoranta J. (2000). Johdatus laadulliseen tutkimukseen. 4. painos. Tampere: Vastapaino.

Frau-Meigs, D. (2013). Transliteracy. Sense-making mechanisms for establishing e-presence. Teoksessa Carlsson, U. \& Culver, S. H. (toim.) Media and information literacy and intercultural dialogue. MILID Yearbook 2013. Göteborg: Nordicom, 175-189.

Frau-Meigs, D. (2015). Augmented Media and Information Literacy (MIL). How Can MIL Harness the Affordances of Digital Information Cultures? Teoksessa Kotilainen, S. ja Kupiainen, R. (toim.) Reflections on Media Education Futures. Göteborg: Nordicom, 13-17.

Fornäs, J. (1995). Cultural Theory and Late Modernity. London: Sage Publications.

Friedenskreis Halle e.V. (2008). Dokumentation der Praxiswerkstatt Transkultur - Potentiale des Ansatzes der Transkulturalität für die Theorie und Praxis der Bildungsarbeit nutzbar machen. Halle. http://www.friedenskreis-halle.de/attachments/ article/136/doku_transkultur.pdf. (12.8.2015)

Gudmunsdottir, S. (1997). Introduction to the Theme Issue of "Narrative Perspectives on Research on Teaching and Teacher Education". Teaching and Teacher Education 13, 1-3.

Hall, S. (2005). Identiteetti. 5. painos. Tampere: Vastapaino

Honkimäki, S. (2001). Going to school at university? Teoksessa J. Välimaa (toim.) Finnish Higher Education in Transition. Perspectives on Massification and Globalization. University of Jyväskylä: Institute for Educational Research, 91-110.
Hull, G. A., Stornaiuolo A., \& Sahni, U. (2010). Cultural Citizenship and Cosmopolitan Practice: Global Youth Communicate Online. English Education 42(4), 331-367. https://www.jstor.org/ stable/23018017?seq=3\#page_scan_tab_contents. (16.3.2017)

Hylland Eriksen, T. (2014). Globalization: The Key Concepts. Second edition. London: Bloomsbury.

Jacobs, G. E. (2012). The Proverbial Rock and Hard Place. The Realities and Risks of Teaching in a World of Multiliteracies, Participatory Culture, and Mandates. Journal of Adolescent \& Adult Literacy 56(2), 98-102.

Jenkins, H., Ito, M. \& boyd, d. (2016). Participatory Culture in a Network Era. New York: Polity Press.

Jenkins, H., Purushotma, R., Weigel, M., Clinton, K. and Robinson, J. (2009). Confronting the Challenges of Participatory Culture. Media Education for the 21st Century. MacArtur Foudantion. https://mitpress.mit.edu/sites/default/ files/titles/free_download/9780262513623_ Confronting_the_Challenges.pdf. (9.9.2015)

Jokikokko, K. \& Järvelä, M.-L. (2013). Opettajan interkulttuurinen kompetenssi - produkti vai prosessi? Kasvatus 44(3), 245-257.

Kim, G. M. (2016). Transcultural Digital Literacies: Cross-Border Connections and Self Representations in an Online Forum. Reading Research Quarterly 51(2), 199-219.

Koehn, P. H. \& Rosenau, H. (2016). Transnational Competence. Empowering Professional Curricula for Horizon Rising Challenges. New York: Routledge.

Koehn, P. H. \& Swick, H.M. (2006). Medical education for a changing world: moving beyond cultural competence into transnational competence. http://www.ncbi.nlm.nih.gov/pubmed/16728804. (30.8.2015)

Koskensalo, A. (2009). Transkulttuurisuuden ja transdisiplinaarisuuden uudet haasteet kielikasvatukselle. Turun yliopiston opettajankoulutuslaitos, Turun yksikkö. (1.10.2015)

Kotilainen, S. (2001). Mediakulttuurin haasteita opettajakoulutukselle. Akateeminen väitöskirja. Tampereen yliopisto.

Kotilainen, S. (2009). (toim.) Suhteissa mediaan. Nykykulttuurin tutkimuskeskuksen julkaisuja 99. Jyväskylän yliopisto.

Kotilainen, S. \& Pienimäki, M. (2017) "Transcultural perspectives needed in media education". School Education Gateway, Europe's online platform for school education. http://www. schooleducationgateway.eu/en/pub/viewpoints/ experts/transcultural-perspectives-nee.htm (18.3.2017) 
Kupiainen, R., Kulju, P. \& Mäkinen, M. (2015). Mikä Monilukutaito? Teoksessa Kaartinen, T. (toim.) Monilukutaito kaikki kaikessa. Tampere: Tampereen yliopistopaino, 14-24.

Laitinen, E., Nokelainen, P. \& Pylväs, L. (2015). Ammattikorkeakoulujen opettajien ulkomailla asumisen kokemuksen vaikutus itsearvioituun kulttuuriälyyn ja sen koettuun tärkeyteen opettajan työssä. Ammattikasvatuksen Aikakauskirja 17(2), 61-81.

Lankshear, C. \& Knobel, M. (2011). New Literacies. Open University press. https://literaturaefilme. files.wordpress.com/2013/08/colin-lankshear-andmichele-knobel-new-literacies-everyday-practicesand-social-learning-third-edition-2011.pdf. (1.6.2016)

Liebkind, K. (2000). Kun kulttuurit kohtaavat. Teoksessa K. Liebkind (toim.): Monikulttuurinen Suomi: Etniset suhteet tutkimuksen valossa. Helsinki: Gaudeamus, 13-27.

Livingstone, S. (2003). "On the Challenges of CrossNational Comparative Media Research". European Journal of Communication, 18 (4), 477-500.

LOPS. (2015). Lukion opetussuunnitelman perusteet. Helsinki: Opetushallitus. http://www.oph.fi/ download/172124_lukion_opetussuunnitelman_ perusteet_2015.pdf. (20.1.2017)

Luukka, M.-R. (2013). Opetussuunnitelmat uudistuvat: tekstien lukijasta ja kirjoittajasta monilukutaituriksi. http://www.kieliverkosto.fi/article/ opetussuunnitelmat-uudistuvat-tekstien-lukijasta-jakirjoittajasta-monilukutaituriksi. (5.8.2015).

Mason, D. (2000). Race and Ethnicity in Modern Britain. Oxford: Oxford University Press.

Matikainen, J. (2015). Mediasukupolvet. Aikuiskasvatus 35(3), 164-176.

Martikainen, T., Sintonen, T. \& Pitkänen, P. (2006). Ylirajainen liikkuvuus ja etniset vähemmistöt. Teoksessa Martikainen, T. (toim.) Ylirajainen kulttuuri: Etnisyys Suomessa 2000-luvulla. Helsinki: Suomalaisen kirjallisuuden seura, Tietolipas 212, 9-41.

Mackenzie, N. \& Knipe, S. (2006). Research dilemmas: Paradigms, methods and methodology. Issues in Educational Research, 16, 2006. 193-205. http:www-iier.org.au/iier16/mackenzie.html. (20.3.2017)

McEvans, H. (1997). The Functions of Narrative and Research on Teaching. Teaching and Teacher Education 13, 85-91.

Mäkinen, M. (2000). Internet yhteisöllisenä mediana. Teoksessa Heinonen, A., Mäkinen, M., Ridell, S., Martikainen, A., Halttu, M. \& Sirkkunen, E. Verkkotorilla. Internet kansalaisviestinnän ja paikallisen julkisuuden tilana. Paikallisuus verkkomediassa - projektin loppuraportti. Tampere: Tampereen yliopisto, 31-56.
New London Group, (2000). "A pedagogy of Multiliteracies: Designing Social Futures. Teoksessa Multiliteracies: Literacy Learning and Designing of Social Futures. (toim.) Cope, B. and Kalanzis, M. London. Routledge.

Nohl, A.-M. (2007). A media education perspective. Cultures of media practice and 'media-bildung'. European Journal of Cultural Studie Vol, 10(3), 415-419.

Opetus- ja kulttuuriministeriö. (2016b). Opettajankoulutuksen kehittämisen suuntaviivoja. Opettajankoulutusfoorumin ideoita ja ehdotuksia. Opetus- ja kulttuuriministeriön julkaisuja 2016:34. Helsinki: Opetus- ja kulttuuriministeriö.

Pathak-Shelat, M., Kotilainen, S. \& Hirsjärvi, I. (2015). A Polycentric Approach to Comparative Research: Reflections on an International Youth Media Participation Study", Journal of Children and Media, 9(3), 386-393. http://www.tandfonline.com/toc/ rchm20/current. (19.3.2017).

Perez-Tornero, J-M. \& Varis, T. (2010). Media Literacy and New Humanism. Institute for Information Technologies in Education. Moscow: UNESCO. http:// iite.unesco.org/pics/publications/en/files/3214678. pdf. (4.6.2016)

POPS. (2014). Perusopetuksen opetussuunnitelman perusteet. Helsinki: Opetushallitus.

Peter, J. \& Valkenburg, P. M. (2006) Adolescent's internet use: testing the disappearing "digital divide" versus the "emerging digital differentiation" approach. Poetics, 34(4-5), 293-305.

Pääjärvi, S. \& Palsa, L. (2015). Entäs aikuiset? Katsaus medialukutaidon edistämiseen digitalisoituvassa Suomessa. Aikuiskasvatus 35(3), 199-207.

Reason, P. \& Bradbury, H. (2006) (toim.) A Handbook of Action Research. London: Sage Publications.

Räsänen, R. (2002). Interkulttuurisen pedagogiikan olemusta etsimässä. Teoksessa Räsänen, R. \& San, J. (toim.) Conditions for Intercultural Learning and Cooperation. Helsinki: Finnish Educational Research Association, 15-34.

Räsänen, R. (2007). Intercultural education for global responsibility. Teoksessa Kaivola, T. \& Melön-Paaso, M. (toim.) Education for Global Responsibility: Finnish Perspectives. Helsinki: Ministry of Education, 17-30.

Sainola-Rodriques, K. (2007). Maahanmuuttajien ja hoitohenkilökunnan kohtaaminen mielenterveyspalveluissa - transnationaalinen taitoko? Sosiaalilääketieteellinen aikakauslehti. http:// ojs.tsv.fi/index.php/SA/article/view/579. (6.7.2016)

Salo-Lee, L. (2005). Kohden kulttuurien välistä kompetenssia. Teoksessa Varis, T. (toim.) Uusrenesanssiajattelu, digitaalinen osaaminen ja monikulttuurisuuteen kasvaminen. Saarijärvi: Saarijärven Offset, 123-134. 
Salo-Lee, L. (2009). Monikulttuurinen osaaminen ja kulttuurinen lukutaito. Teoksessa Lampinen, J., Melön-Paaso, M. (toim.) Tulevaisuus meissä: Kasvaminen maailmanlaajuiseen vastuuseen. Opetusministeriön julkaisuja 2009:40, 65-70.

Schütz, A. (2003). Strukturen der Lebenswelt. Konstanz: UVK Verlagsgesellschaft, Band 1.

Sihvonen, J. (2009). Medialukutaidon rajat ja rajoitukset. Teoksessa Kotilainen, S. (toim.) Suhteissa mediaan. Jyväskylä: Gummerus kirjapaino Oy.

Säljö, R. (2004). Oppimiskäytännöt. Sosiokulttuurinen näkökulma. Juva: WSOY.

Suomen virallinen tilasto (SVT): Oppilaitosten opiskelijat ja tutkinnot [verkkojulkaisu]. Julk. 29.11.2016. Helsinki: Tilastokeskus. http://www.stat.fi/til/opiskt/ index.html. (20.3.2017)

Tuomi, J. \& Sarajärvi, A. (2006). Laadullinen tutkimus ja sisällönanalyysi. Jyväskylä: Tammi.

Tynjälä, P. (1999). Oppiminen tiedon rakentamisena. Konstruktivistisen oppimiskäsityksen perusteita. Tampere: Tammer-Paino Oy.

UNESCO. (2001). Universal Declaration on Cultural Diversity.
Welsch, W. (1995). Transkulturalität. Zur veränderten Verfassung heutiger Kulturen. Zeitschrift für Kulturaustausch, "Migration und kultureller Wandel" 45(3), 39 -44. http://www.forum-interkultur.net/ uploads/tx_textdb/28.pdf. (12.10.2015)

Welsch, W. (1999). Transculturality - the Puzzling Form of Cultures Today. Teoksessa Featherstone, M. \& Lash, S. (toim.) Spaces of Culture: City, Nation, World. London: Sage Publications, 194-213.

Varis, T. (1998). Viestintäkasvatuksen haasteet ajan kuvana: johdatusta mediakompetenssien merkitykseen. Teoksessa Kivikuru, U. \& Kunelius, R. (toim.) Viestinnän jäljillä: näkökulmia uuden ajan ilmiöön. Helsinki: WSOY, 375-391.

Vettenranta, S. (2013). Global Mediagraphy. A Teaching Method in Media Education. Teoksessa Carlsson, U. \& S. Culver, H. (toim.) Media and information literacy and intercultural dialogue. MILID Yearbook 2013. Göteborg: Nordicom, 175-189.

Vygotsky, L. S. (1982). Ajattelu ja kieli. Helsinki: Kansankulttuuri. 